\title{
The tangled politics of conservation and resource extraction in Mozambique's green economy
}

\author{
Kate Symons ${ }^{1}$ \\ University of Edinburgh, Scotland, UK
}

\begin{abstract}
This article explores how Mozambique's green economy has been produced through the intersection of global ideas about green development, regional economic development dynamics, and local debates and political pressures around extraction and conservation. Mozambique's green economy aims to compress many of its current challenges into a seemingly attractive and compelling agenda. The green economy discourse has produced a new relationship between the conservation and extractives sector, characterized by 'green' financing and offsetting measures intended to handle (at least on paper) the contradictions between extractives-led growth and sustainable development. However, the green economy vision has also provided specific actors with ways to contest extraction. The article provides a lens onto the production of green economy policies and institutions in Mozambique, the way the policy combines neoliberal and non-neoliberal political ideas, and how green economy ideas are played out in the situated politics of debates over conservation and extraction. I consider how 'the' green economy is reworked through tracing a particular case - the recent debates over whether a large coal port should be built in the Ponta do Ouro Marine Reserve. This foregrounds the multiple and often ambiguous uses of green economy discourses to pursue different, and sometimes contradictory agendas. The article contributes new empirical information on the roll-out of green economies in a developing country context, while also seeking to expand current political ecology literature on neoliberalism and green economies more generally.
\end{abstract}

Key words: Mozambique, green economy, neoliberal nature, extractives, conservation, assemblage

\section{Resume}

Cet article explore la manière dont l' économie verte du Mozambique a été produite, à la croisée des idées mondiales sur le développement vert, des dynamiques régionales de développement économique, des débats locaux, et des pressions politiques autour des industries extractives et de la conservation de la nature. L'économie verte du Mozambique vise à condenser nombre de ses défis actuels en un programme d'apparence attrayant et convainquant. Le discours sur l'économie verte a créé une nouvelle relation entre le secteur de la conservation et les industries extractives, celui-ci est caractérisé par des mesures de financement et de compensation « vertes » destinées à solutionner (au moins en principle) les contradictions entre la croissance économique poussée par les industries extractives et le développement durable. Cependant, l'économie verte a également fourni à des acteurs spécifiques des moyens de contester les industries extractives. L'article fournit une nouvelle perspective sur la production des politiques et des institutions de l'économie verte au Mozambique, la manière dont ces politiques combinent des idées politiques néolibérales et non néolibérales, et la manière dont les idées de l'économie verte sont utilisées dans la politique des débats sur la conservation et les industries extractives. J'étudie la façon dont l'économie verte est retravaillée en retraçant l'histoire d'un cas en particulier: les récents débats sur la question de savoir si un grand port charbonnier devrait être construit dans la réserve marine de Ponta do Ouro. Ces débats mettent en exergue l'utilisation multiple et souvent ambiguë des discours sur l'économie verte pour poursuivre des programmes différents et parfois contradictoires. L'article apporte de

\footnotetext{
${ }^{1}$ Dr. K. Symons, Centre of African Studies (CAS), University of Edinburgh, Chrystal Macmillan Building, 15a George Square, Edinburgh, EH8 9LD, UK. Email: K.symons "at" ed.ac.uk. I would like to express my gratitude to Brian Mather for designing the maps in this article, to colleagues in CAS, Jean- Benoît Falisse and Tatianna M.P. Silva for helping with translation, and to Ben Garlick for providing comments on an early draft of this article. I also thank the editorial and review team at the Journal of Political Ecology for strengthening this article though their insightful questions and comments.
} 
nouvelles informations empiriques sur le déploiement des économies vertes dans le contexte de pays en développement, tout en cherchant également à élargir le corpus de la littérature en écologie politique sur le néolibéralisme et les économies vertes en général.

Mots clés: Mozambique, économie verte, nature néolibérale, industries extractives, conservation, assemblage

\section{Resumo}

Este artigo explora como a economia verde de Moçambique foi produzida através da interseção de ideias globais sobre desenvolvimento verde, dinâmicas de desenvolvimento econômico regional e debates locais e pressões políticas em torno da extração e conservação. A economia verde de Moçambique pretende reduzir muitos dos seus desafios atuais a uma agenda aparentemente atrativa. O discurso da economia verde produziu uma nova relação entre o setor de conservação e extrativismo, caracterizado pelo financiamento "verde" e pela compensação de medidas destinadas a lidar (pelo menos no papel) com as contradições entre o crescimento extrativista e o desenvolvimento sustentável. No entanto, a visão da economia verde também forneceu a certos atores maneiras de contestar a extração. O artigo analisa a produção de políticas e instituições de economia verde em Moçambique, a forma como a política combina ideias neoliberais e não-neoliberais, e como as ideias da economia verde se desenrolam na política dos debates sobre conservação e extração. Eu examino o modo como a 'economia verde é reconstruída através do estudo de um caso particular - os recentes debates sobre a construção de um grande porto de carvão na Reserva Marinha da Ponta do Ouro. A questão evidencia os usos múltiplos e muitas vezes ambíguos dos discursos sobre economia verde que podem fundamentar agendas diferentes e às vezes contraditórias. $\mathrm{O}$ artigo contribui para a geração de um conhecimento empiríco novo sobre a expansão das economias verdes no contexto de um país em desenvolvimento, enquanto colabora para o aprofundamento da literatura sobre ecologia política sobre o neoliberalismo e as economias verdes.

Palavras-chave: Moçambique, economia verde, natureza neoliberal, extrativismo, conservação, assemblage

\section{Introduction}

To produce a commodity is the work of the translator, the diplomat and the power crazed magician (Tsing 2005: 51-52).

In 2012, Mozambique launched its Green Economy Roadmap at Rio20+, and declared green capitalism as "the future that we, Mozambicans, want [and] the future that the rest of humanity dreams about" (thenPresident of the Republic of Mozambique, Armando Guebuza, quoted in WWF press release, WWF 2012a). Green economy policies have been presented by major donors and development institutions as a solution to ensure environmental protection, socially equitable outcomes and economic growth in developing countries, claiming to be "pro-growth, pro-jobs, and pro-poverty-reduction" (UNEP 2011: 6-7). Green economy discourses have also attracted the attention of political ecologists, who theorize green economies as a way of creating and institutionalizing ways to greenwash ecological contradictions, and profit from new so-called green products and services. Green economies privilege a view of nature as natural capital, in which development goals can be met through simultaneously exploiting and protecting a country's natural resource base. They are often viewed as contradictory, displaying the "core fantasy of neoliberal environmental governance whose 'purpose' obfuscates the impossibility of succeeding in the reconciliation of ecological sustainability with longterm economic growth" (Sullivan 2017: 231). Consequently, green economies are viewed by political ecologists as deepening the neoliberalization of nature through conjuring new 'green' commodities.

However, while there have been several analyses which focus on the construction of the green economy as a discursive truth regime, there has been less attention from political ecologists on how these policies have actually been adopted and reworked in particular national contexts (Buseth 2017; Vladimirova 2017). This article seeks to expand current debates in political ecology by exploring the construction and mobilization of Mozambique's green economy, as mediated through its contentious resource politics. In Mozambique, the green economy has taken on distinct characteristics which reflect the country's historic and contemporary political- 
economic context, and is mobilized in different ways in national development debates. The strategy has been presented as a way to help Mozambique manage its extractives-led growth in ways which protect and even enhance its natural environment, an appealing 'fix' where conservation and extraction are in conflict. However, Mozambique's green economy also departs from neoliberal orthodoxy in some respects, and has also been reworked in specific circumstances in ways which contest some of its original goals. The research goal guiding this article is, therefore, to consider whether the neoliberal nature literature is sufficient to understand the emergence, shape and mobilization of Mozambique's specific green economy. The article contributes new empirical information on the roll-out of green economies in developing country contexts, while also seeking to expand current political ecology literature on neoliberalism and green economies more generally.

I expand on current theoretical approaches to the green economy, which often draw on neoliberal nature critiques by using Tania Murray Li's conceptualization of assemblage as political practice, to explore how

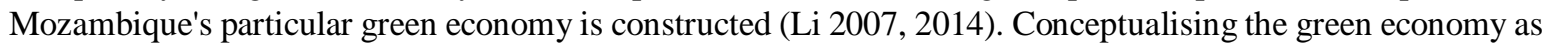
an assemblage draws attention to the political work that is done to frame development and environmental problems in Mozambique, and the ways in which the green economy holds together many contested ideas into an agreed intervention (Li 2014; Tsing 2005). This article considers how this work is conducted, what problems Mozambique's green economy purports to solve, and in whose interests. Conceptualizing Mozambique's green economy as assemblage facilitates a move away from a totalising or hegemonic "march of triumphal green capitalism" (Fairhead et al. 2012: 254), and explores aspects of green economy politics which are not often foregrounded in recent political ecology work on the subject.

The article begins by setting out research context and methods, and current theoretical framings of the green economy, highlighting literatures from development anthropologists which help expand current political ecology thinking. I then discuss the three 'uses' of the green economy in Mozambique: The first use is as national development vision. There are significant aspects of Mozambique's strategy that attempt to rework neoliberal development models, for example, in its focus on large-scale public spending on major infrastructure, and its explicit commitments to ecologically and socially beneficial development delivered through modifying the behavior of the market through the state. These, I suggest, can be traced through to Mozambique's postindependence claims about natural resources and development, along with current pressures to manage debt while meeting national development ambitions. The second is as ecological fix for extractives-led development, driven by major donors like WWF Mozambique. This assessment is broadly in line with current political ecology work which emphasizes the neoliberal aspects of the global green economy discourse.

Finally, using the example of the contested Techobanine port complex, proposed for the Ponta do Ouro Partial Marine Reserve, I explore how some conservationists have mobilized the green economy discourse to oppose this specific extractives-led project. The actors I describe used green economy ideas in highly strategic ways to contest Mozambique's extractive agenda, even as the strategy is intended to make conservation and extraction more compatible. I conclude by reflecting on how Mozambique's green economy is an attempt to deal with multiple contradictions in its contested resource politics, and the questions this raises for future political ecology work in researching the situated politics of conservation, extraction, and green development.

\section{Research methods and context}

The article is based on six month's field work conducted late 2013 and early 2014, based in the Ponta do Ouro Partial Marine Reserve (PPMR) in the Lubombo Trans-frontier Conservation Area, and in Maputo where many of Mozambique's national government and donor organisations are based. I conducted 42 semi-structured interviews across donors, government officials (including senior officials from the following organisations: ANAC, National Administration for Conservation Areas (Administração Nacional das Areas de Conservação); MICOA, Ministry for Coordination of Environmental Affairs (Ministério para a Coordenação da Acção Ambiental) and MITUR, Mozambican Ministry of Tourism). I interviewed conservation professionals from those NGOS discussed in the article, PPMR reserve officials, reserve management from other national parks in Mozambique, civil society organization members, international donors and community members in the PPMR conservation area. I also conducted subsequent telephone and Skype interviews with key informants throughout 2015 and 2016. I attended a Conservation Policy in Mozambique workshop held in Maputo on 22-24 April 
2014, organized by USAID and attended by several government officials and conservation professionals. This event provided an opportunity to see how economic development, conservation, and resource politics were produced and debated. I follow Corson, MacDonald and Neimark who "situate international conferences as critical moments in the production of hegemonic environmental discourses" (2013: 11), but also draw on Tsing (2005), who suggests that such events throw light onto how such apparently hegemonic discourses are contested and re-assembled through being negotiated in particular contexts. Finally, I analyzed green economy documents and conservation regulatory reforms, and followed the rumours and speculation about the Techobanine port through various media outlets and email contact with the PPMR reserve management (AfDB 2011; Government of Mozambique 2012a, 2012b, 2013).

The PPMR is a $650 \mathrm{~km}^{2}$ mixed-use marine reserve which stretches for 300 coastal kilometres from St Lucia in South Africa to Maputo Bay in Mozambique. The park forms part of a larger trans-frontier conservation area (TFCA), the Lubombo, which combines five land and coastal reserves across Mozambique, Zambia and South Africa into a single park. The Lubumbo and the PPMR were proposed and are managed by the Peace Parks Foundation (PPF) which promotes TFCAs throughout southern Africa. The PPMR and the Lubombo are shown in Figure 1. TFCAs promise a 'triple-win' development formula of regional biodiversity protection, economic growth and political co-operation, exemplifying many of the central tenets of neoliberal green development (Büscher 2013). The PPMR aims to support sustainable development for Mozambique through this kind of conservation-led economic regeneration, particularly through community incentives such as a community lodge and through conservation-led tourism. This model is presented as offering a long-term vision for Mozambique in contrast to the present Frelimo emphasis on industrial development and extractives.

In contrast to the PPF's vision, there is a rival plan for the area. It is also envisaged as an industrial hub complete with a deep water port to facilitate investment in mining, logistics and industry, supported by prominent politicians in Zimbabwe, Mozambique and Botswana. The Techobanine Port proposals are part of a proposed US $\$ 600 \mathrm{~m}$ rail project to export coal and other goods from landlocked Botswana through Mozambique (Macauhub.com September 2016). Rumours of a port at Technobanine date from colonial times, but have never materialized and rumours have come and gone. The designation of the PPMR and its incorporation into the Lubombo was supposed to quash rumours for good. However, speculation about the port resurfaced in 2010, and again in 2016 and 2018, and the situation has remained extremely uncertain. For a period there were good reasons to consider that the port may not be financially viable: Botswana's coal industry hit technical difficulties in 2015, while also facing the impact of a global slowdown in demand for coal and the Paris Declaration of the same year which discouraged futher development of coal infrastructure. However, the port was revived again in April 2018, along with the rail scheme which would link Francistown in Botswana and Bulawayo in Zimbabwe with the new port at Techobanine. This time, the scheme is couched in terms of regional trade, and has attracted high-profile supporters from Zimbabwe, Botswana and Mozambique. It is significant that port plans were revived immediately after Botswanan President Mokgweetsi Masisi and President Emmerson Mnangagwa of Zimbabwe assumed office in April 2018 and November 2017 respectively. Botswana's outgoing President, Ian Khama was a known supporter of the rail and port proposals, and President Masisi has reiterated this support (Southern Times 2018). The port's main Mozambican proponent, General Jacinto Veloso², is an influential former Frelimo security minister who claims to own some of the land in which the port complex is proposed (interview with Mozambican NGO, Maputo, 26 April 2014). Media articles have publicised various announcements throughout 2012-2018, most recently in April 2018, when several outlets reported that the governments of Mozambique, Botswana and Zimbabwe met to renew interest in the port proposals and the accompanying rail development (Club of Mozambique April 2013; May 2016; April 2018). One informant claimed to know about secret meetings conducted between the Ministry of Transport and Commuications and Veloso in order to secure land rights for the port as early as 2012, and characterised the individuals present as a Frelimo cartel behind the development. While it may be that the port has finally found its political moment

\footnotetext{
${ }^{2}$ Veloso has several business interests in the extractives sector including Pathfinder Minerals which exports substances used in ceramics, and was recently controversially linked to the UK Conservative Party via former Africa Minister, Henry Bellingham (The Telegraph, November 2014).
} 
thanks to recent regional geopolitical shifts, the history of contestation by conservationists against the port demonstrates the uses of green development ideas in the specific Mozambican context.

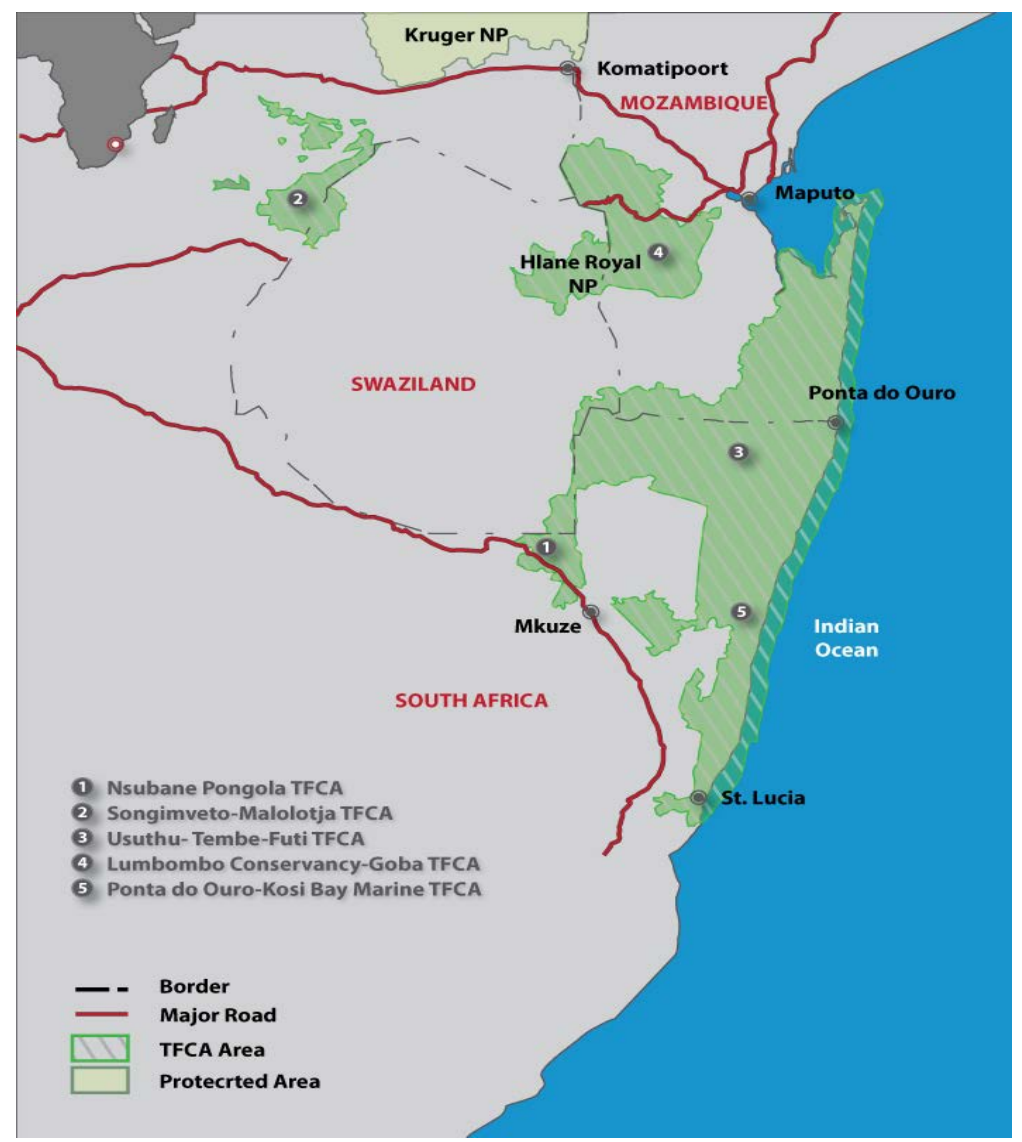

Figure 1: Map of the Lubombo Trans-frontier Conservation Area. Map designed by Brian Mather.

The two visions for the PPMR are on the face of it, are deeply contradictory, but as scholars of neoliberal nature have theorized, green development attempts to fix the fundamental contradiction produced by extractive capitalism by creating new opportunities for 'green' capitalist expansion. Mozambique's new green economy policies could allow the port could be constructed, provided developers offset the damage elsewhere. Yet, in 2016, the PPRM reserve management contested the port proposals by reworking claims about green development to challenge the government's extractives agenda, securing a UNESCO designation which is a significant obstacle to any major port in the area. This case provides a focal point to understand how how green economy ideas are being institutionalised and reworked to support particular government and donor agendas, as well as giving first-hand insights into how conservationists mobilise green economy discourses in a contested scenario.

\section{Theorising the green economy}

Financialization has become a mainstream response to environment crises. 'Greening the economy' forms a dominant policy strategy in major environmental institutions, several states and donors, replacing the 
sustainable development discourses of the Rio 1992 conference and initiatives (Brand 2009). The United Nations Environment Program (UNEP) defined a green economy as follows:

In its simplest expression, a green economy can be thought of as one which is low carbon, resource efficient and socially inclusive. In a green economy, growth in income and employment should be driven by public and private investments that reduce carbon emissions and pollution, enhance energy and resource efficiency, and prevent the loss of biodiversity and ecosystem services. (UNEP 2011: 1)

The Organisation for Economic Cooperation and Development (OECD 2011: 9) places a similar emphasis on economic growth, stating that "green growth means fostering economic growth and development while ensuring that natural assets continue to provide the resources and environmental services on which our well-being relies". The World Bank suggests that "green growth is about making growth processes resourceefficient, cleaner and more resilient without necessarily slowing them" (Hallegatte et al. 2011, cited in Resnick, Tarp and Thurlow 2012: 217). Green economies are thus thought to be particularly relevant to developing countries, and in such contexts emphasise reworking environmental governance by reframing natural resources as sources of economic growth (Nhamo 2013). Green development advocates suggest that capital and donor investment in developing countries can turn away from 'unsustainable' development like fossil fuel extraction and unsustainable forestry, towards strategies like conservation-based tourism, bioprospecting and payments for ecosystem services (Huberman 2010).

While green economy strategies invoke the 'win-win' between economic development and positive environmental outcomes familiar from sustainable development discourses (see World Commission on Environment and Development 1987), the green economy does not simply repackage historic ideas. Rather, new techniques and policies are considered necessary to refine neoliberalism in the face of previous crises (Bakker 2010; Peck 2010). The green economy is the latest policy innovation in ecological modernization, and altered successor to the sustainable development discourses of the 1980s, 1990s and 2000s (Adams 2017; Davidson 2012; Sullivan 2017; Wanner 2015). The key hoped-for corrective at the heart of green economy thinking is to make preserving rather than degrading nature valuable within the capitalist system by decoupling economic growth from the exploitation of ecologies. For its advocates, the green economy offers a way to recognize and mitigate the long-term negative social and ecological implications of standard capitalist growth (P. Ferguson 2015). This goal underpins a growing number of concrete green economy policies and strategies that are rolling out in diverse contexts, including South Africa, the United States, Mozambique, Tanzania, Greece and Russia (Buseth 2017; Death 2014; Resnick, Tarp and Thurlow 2012; Siamanta 2017; Vladmirova 2017; Wanner 2015).

Green economy policy initiatives often include the construction of markets, such as trading in carbon emission privileges or rewarding the protection of ecosystems through payment schemes. They also encourage the private sector to invest in ecologically-friendly schemes. The goal is to reframe capitalism from a cause of ecological depletion to a source of effective response (Nhamo 2013; OECD 2011; UNEP 2011; WWF 2015). However, scholars argue that this fundamentally misinterprets capitalism, which undermines social and ecological conditions, and consequently argue that green economy strategies serve three goals:

- to 'green wash' the conventional exploitation and commodification of nature

- to provide new opportunities to accumulate through 'green' products and services

- and to shut down more progressive or sustainable alternatives (Moore 2015; Sullivan 2017; Turhan and Gündoğan 2017)

One area singled out for critique is the deepening and extending of linkages between conservation institutions and the private sector, particularly the extractives industry. Adams (2017) reports a growth in formal partnerships between the mining sector and conservation bodies such as The International Council on Mining and Metals (ICMM), which claims to "integrate mining and biodiversity conservation" (ICMM 2004). 
Increasingly, conservation organisations are willing to "share platforms, board membership, and apparently values with corporations" (Adams 2017: 244; see also Büscher and Davidov 2013; Ramesh and Rai 2017). The benefits to industry, Adams argues, are obvious, as links with conservation organisations provide mitigation for ecologically exploitative activities, usually in the form of biodiversity offsetting. However, while the benefits to conservation may be clear in the short term (in the form of increased funding and influence), the long term consequences are the material and ideological restructuring of conservation to work in the interests of capital. Adams (2017: 243) characterizes this as a pact with the devil in which long-term conservation goals are sacrificed on the altar of short-term pragmatism.

Scholars have recently acknowledged the tension between theorizing 'the' green economy as a coherent and singular policy approach to development, and they have pointed out variegations in actually existing green economies (Cavanaugh and Benjaminsen 2017; Death 2014). In a review of 24 green economy policies, Bina (2013) identifies a spectrum between the 'almost business as usual' approach suggested by the European Commission which simply amounts to including green products and services in economic plans as a way of stimulating existing economies, to a much more radical 'all change' philosophy, in which economic growth is replaced by degrowth and the use of alternative indicators such as human well-being, pursued by bodies such as left-leaning think tank The New Economics Foundation and others. Tienhaara (2014: 194) also notes significant variations among green economies which amount to "different visions of an ideal capitalist society." These include:

- 'green new deal' formulations based on shifts to low economic growth

- investment in renewable energy

- some carbon trading and pricing and regulation of financial sector

- 'green stimulus' philosophies which adopt a 'green growth' perspective based on using technologies and financialization to provide new opportunities for growth

- and, full-blown 'green economies' which add further financialization measures such as natural capital accounting and measures to make biodiversity conservation a contributor to growth.

For example, Wanner (2015) describes how the green economy in the United States represents a departure from 'business as usual' neoliberal capitalism by acknowledging that continued neoliberal growth has been responsible for ecological crises, and urging a change in economic doctrine to include the state control of markets and limitations to the free movement of capital in the interests of solving social and ecological problems. The US version also suggests large-scale government and private investment into projects and infrastructure, which is not in keeping with the ideology of small-government, free-market neoliberalization. In short, there are good reasons to reject the automatic shorthand adopted by some political ecologists which run together significantly different policy initiatives into 'the' neoliberal green economy, and pay close attention to different policy plans and discourses in different contexts.

Nevertheless, much of the recent political ecology work on the green economy work tends to end up in the same place, politically speaking. The politics of the accounts of neoliberal nature and green capitalism discussed above are often rooted in what development anthropologist Ferguson (2015: 31) calls "the politics of the anti", focused solely on seeking out and condemning examples of neoliberal policy development - "the necessary and nefarious presence of a sinister 'big Leviathan' known as neoliberalism." Ferguson highlights the shortcomings of this research agenda in two ways. First, in seeking out and denouncing examples of neoliberal policy development, scholars are in danger of leaping to normative conclusions without further considering the functions that green economy ideas might have in wider political economies. This risks missing the ways in which ideas which may be neoliberal at a policy level can be mobilized by a variety of different actors to achieve goals that are not necessarily those intended at the outset, and which can contest or rework the original policy intentions. Second, the overwhelming critical attention on neoliberalism fails to attend to non-neoliberal political ideologies and practices which are also playing important roles in development. A similar point has been made by Karen Bakker (2009), who suggests that the analytic of ecological fix presumes that the sole purpose of neoliberal nature policies is to maximize profit or mediate tensions in a capitalist system. However, 
as she argues (2009: 1783) there are a "broad array of goals - political, social, cultural, and environmental which both drive and mediate the neoliberalization of nature......... which often have a tangential and uneasy relationship with neoliberal projects." Ferguson and Bakker reinforce empirical work, discussed above, which distinguish between several actually-existing green economies and neoliberal orthodoxy. In short, a political focus on the politics of the anti misses the ways that policies like Mozambique's green economy (which undoubtedly contains much that might be labelled neoliberal), nevertheless incorporates other political ideas, and can be mobilized in multiple ways. And, an analytical focus which privileges the ecological fix may miss the way that neoliberal policies sit alongside other development discourses and visions.

Assemblage theory helps to develop Bakker's and Ferguson's critiques. Assemblage is an active process "to direct, conduct and intervene in social processes to produce desired outcomes and avert undesirable ones" (Li 2007: 264). It produces an "identifiable terrain of action and debate", in which a number of actors work together to organise social worlds and direct actions towards a particular social outcome (Li 2007: 266). Mozambique's green economy can be seen as a specific terrain of action and debate, in which the interests of different audiences are united under an agreed world view and set of actions. $\mathrm{Li}$ also draws attention to contingency in an assemblage, whereby "elements are drawn together at a particular juncture only to disperse or realign, and the shape shifts according to the terrain and angle of vision" (Li 2007: 265). Initiatives like 'the' green economy are tenuously and contingently brought together through encounters between actors who have their own political goals and accumulation strategies, who adopt claims and counterclaims based on particular ideas of development, and who work hard to maintain a world view in the face of tension and friction (Tsing 2005). As such, globalized and internationalist ideologies are locally reconfigured according to contextual political debates and needs (Buseth 2017). Green economy policies help actors negotiate particular forms of social, institutional and political life (even as they appear discursively as a form of direct financial accumulation or ecological fix). An assemblage analysis has much to offer political ecologists of the green economy, providing a way of acknowledging the situated politics of specific green economies, and the multiple and pragmatic ways that neoliberalization processes can be shaped, contested and mobilized by a variety of actors. With this in mind, I move now to explore the dynamics which are assembling Mozambique's particular green economy.

\section{Assembling Mozambique's green economy}

In the following discussion, I explore the multiple challenges which the green economy purports to solve, and the actors which are shaping and using the green economy to achieve particular political ends. I do not provide a chronological story of the introduction of the green economy, but rather draw out first its nonneoliberal aspects, then its neoliberal features and their uses, before returning to the case of the port to show how the ideas are mobilized.

\section{From donor darling to green economy star: a vision for a new Mozambique}

Since its emergence from conflict and its adoption of capitalism in 1991, Mozambique has been a site of policy experimentation by its domestic elites and by international donors and institutions (Harvey 2005; Sidaway and Power 1995) Throughout the the 1990s and 2000s, the country was celebrated as an example of the accomplishments of the Washington Consensus and trade-led development due to its comparatively high levels of growth and significant levels of foreign direct investment (Hanlon and Smart 2008). More recently, the country has intensified extractives-led and industrial development, leading to further scripting of Mozambique as an economic success story and investment frontier (Blanco Armas et al. 2014). Gas, coal, industrial fishing and agriculture, and other mega-projects are booming across the country, and growth rates averaged 7 per cent per year between 2008 and 2015, largely as a result of the coal, heavy industry and largescale agriculture sectors. The recent discovery of globally significant amounts of natural gas in its northern waters in 2010 led to celebrations of Mozambique as one of Africa's "new investment frontiers" (Vines 2013: 1).

However, the success story narrative has consequently looked increasingly fragile of late. Ruling party Frelimo (The Mozambique Liberation Front, Frente de Libertação de Moçambique, which has been in 
government in Mozambique since handover of power from Portugal in 1974) is viewed by many as seeking to rapidly expand Mozambique's extractives sector, regardless of social or ecological costs, in order to serve private accumulation rather than national interest (Castel-Branco 2014; Hanlon, 2016; Kirshner and Power 2015). One informant described this as "a resource scramble amongst the elite" (interview with donor, 2 May 2014). Similarly, a Mozambican government official, discussing the country's governing party's view of conservation in the context of the resources boom described how ecosystems figure as "an afterthought", because "they [Frelimo] want economic growth at any price" (interview with MICOA, Maputo, 14 May 2014). Several recent projects, such as the controversial US gas company Anadarko's gas processing plant near Palma in the north have been the subject of opposition and contestation from communities, and critical voices from civil society observe a government pursuing an extractives agenda regardless of social or ecological outcomes (Centro de Integridade Publica Mocambique 2014; Santos et al. 2015). Hopes about greater public spending, promised by Frelimo, have recently been quashed by Mozambique's debt crisis of 2016, when the Government revealed that its public debt was US\$14 billion, approximately US $\$ 2$ billion more than had been reported. Public finances are being reworked to service the debt and make up a shortfall in promised capital spending on gas infrastructures, and some Frelimo members are urgently seeking new development narratives which will enable them to reshape the country's trajectory in favour of more broad-based development (Hanlon 2016). The green economy provides a way to do just this, and is being positioned as a vision for a "new Mozambique" which directly deals with the country's current challenges, enables it to learn from its past mistakes, and provides tangible economic benefits (interview with former Frelimo minister, April 2014).

Mozambique's green economy strategy is ambitious, with Mozambique heralded as one of Africa's "rising green economy stars" in 2013 (Nhamo 2013: 124). The strategy was initially published as the Green Economy Roadmap, launched at Rio20 + in 2012, and a subsequent Mozambique Green Economy Action Plan was approved by the Council of Ministers on October 15th, 2013. There is also a policy white paper and set of costs from the African Development Bank (AfDB) (2015), which represents a more extensive "attempt to incorporate green growth principles in national policy planning" (AfDB 2015: 60), as well as provide concrete policy prescriptions for distinct sectors, alongside a short statements and speeches by donors such as the WWF and the United Nations Development Programme (UNDP) (AfDB and WWF 2011; UNDP 2015). The strategy defines the green economy as follows:

A green economy is one which values and invests in natural capital - incorporates the Earth's assets (soil, air, water, ocean, flora and fauna) and all its ecosystem services into economic growth and social considerations. Ecosystem assets and benefits are essential for humanity, since they provide food, fiber (sic), water, health, climate stability, energy, amongst other essential services; and builds social capital which contributes to the eradication of poverty - establishes relations between persons, organizations, laws, and policies that promote equitable distribution of the benefits that come from the use of natural capital. (Government of Mozambique 2012a: 7)

As described in this definition, and discussed further in this section, significant parts of Mozambique's green economy policy strategy is based on neoliberal principles of natural capital mapping and the incorporation of ecosystem services into economic planning. The strategy also promotes payments for ecosystem services, and places a high priority on conservation-led tourism, along with, as discussed, enabling a closer relationship between the extractives sector and conservation. This is the "re-evaluation [of nature] in capitalist terms" characteristic of neoliberalism (Büscher et al. 2012: 4). However, the strategy also moves away from classic neoliberal orthodoxy of deregulation (as described by Brenner et al. 2010 and Castree 2008). It instead advocates restricting public spending in areas that reduce natural capital, and sets out tax incentives to stimulate the green economy market. It advocates large-scale spending (from donor, government and private sector investment) into transport, water, energy, urban development, land planning, agriculture, forestry and fisheries. Recent major gas discoveries in the north of the country, along with donor funding will facilitate the nationallevel investment into green economy projects and infrastructure (AfDB 2015). In this way, the green economy 
is intended to address Mozambique's need for broad-based economic growth and job opportunities, a promise which has not been met by the conventional industrial and extractives sectors. This departure from neoliberal orthodoxy is significant; Mozambique's green economy vision consists of major investment across large-scale project-based infrastructure along with tax incentives and duties. This has more in common with Mozambique's historic enthusiasm for the creation of modern infrastructure throughout the country as promoted by independence Frelimo politicians, and contemporary politicians in their current enthusiasm for industrial megaprojects, than it does with small-government, free-market neoliberalism (Mondlane 1969). Recalling Tienhaara's (2014) typology of green economies, Mozambique's strategy encompasses characteristics from different types. It resembles green new deal formulations in its emphasis on measures like renewable energy which are intended to support the economic status quo. In its imagining of a strong investing state and 'carrot and stick' taxation policy, it undoubtedly acknowledges that unfettered markets cannot solve social and ecological challenges. At the same time, the strategy also incorporates 'green stimulus' ideas based on using technologies, investment and financialization to provide new opportunities for growth through new green products and services, along with measures to make biodiversity conservation a contributor to growth (what Tienhaara shorthands as full blown green economies). Mozambique's green economy is a hybrid of different visions.

To reflect briefly here, I draw once again from Ferguson (2015), who points out the other political registers which can be built in to policies that also contain neoliberal aspects. Mozambique's particular green economy vision re-introduces the idea that the state must control markets through active fiscal policy and heavy state investment. These ideas sit alongside conceptualizations of nature as best managed through market logic. We also see the addition of a temporal fix, in which the promise of a future post-extractive economy depends on the short-term financial stimulus offered by major gas discoveries. Mozambique's green economy must therefore be understood in terms of its particular political history and political economy, and the ways in which it compresses several problems currently experienced by Mozambique's political economy into a clear political strategy. I now turn to draw out its particular relationship with the extractives sector, and the ways in which Mozambique's green economy also contains policies which encourage the financialization of nature.

\section{Mozambique's green economy as a response to the extractives boom}

This section discusses how the nature financialization aspects of Mozambique's green economy have been driven by particular donors seeking a response to Mozambique's extractives boom. International NGOs and donors have been highly influential in Mozambique since the 1980s and early 1990s, providing the government with resources, policy and funding, and placing key personnel into government departments (Abrahamsson and Nilsson 1995). This has been particularly obvious in conservation, where NGOs and private philanthropists have been very active in promoting large scale conservation areas, motivated by the idea of Mozambique as a post-conflict arena in need of restoration back to an idealised former glory (Walker 2015). More recently, coinciding with Frelimo's intensifying pursuit of growth through heavy industry and resource extraction, some donors and NGOs have sought to position conservation as a key response to intensifying industrial and extractive development. This involves both protecting nature from development, but, crucially, also finding ways to benefit from it in ways which are aligned with the extractives sector (World Bank interview, Maputo, April 2014). Influence within government has been easily secured by large international donors and NGOs which have provided ways to align conservation goals with Mozambique's rapid industrialization. These include in particular WWF Mozambique, and the Green Economy Joint Programme (GEJP) which comprises the United Nations Environment Programme (UNEP), the United Nations Department of Economic and Social Affairs (UNDESA), the International Union for the Conservation of Nature (IUCN), USAID (which has a particular interest in biodiversity conservation), and the Peace Parks Foundation.

WWF Mozambique has been especially important to setting up Mozambique's green economy. A meeting between WWF Mozambique and the then President of the African Development Bank, Donald Kaberuka, in July 2011 in Tunis was a key point in the development of Mozambique's green economy strategy. Kaberuka who invited WWF to put forward partnership ideas on issues including "climate adaptation, mitigation, biodiversity and ecosystems, as well as the proposed Green Fund for Africa." At the meeting, the 
AfDB "expressed the Bank's willingness to learn from the wealth of expertise of WWF" in pursuit of "the promotion of environmentally sustainable development" (AfDB and WWF 2011, no page). Mozambique's initial green economy policy roadmap was the product of a Green Economy Conference held in Maputo in April 2012, again initiated by WWF Mozambique. This regional conference aimed to link the strategies of Kenya, Tanzania and Mozambique, and largely reflected WWF's regional Coastal East Africa strategy (WWF 2012b, 2013).

One of the central planks of WWF's green economy vision is the idea of the compatibility between the extractives sector and green development, in line with global green economy discourses as well as local priorities (Huberman 2010). WWF argued that "new revenue to be generated by growing oil, gas and mineral extraction sectors can play a strong role in supporting sustainable development and the transition to a Green Economy" (WWF 2012b: 1). This introduced the idea that the extractives sector could provide financial contributions to support conservation to promote its corporate social responsibility programme and its social license to operate, a view which later became supported by other green economy players in Mozambique such as the Biofund (interview with Biofund official, Maputo, 9 May 2014). WWF began extensively promoting the idea that extraction could actively support conservation. Mozambique's economy was booming due to extractive and industrial development during this same period, and underpinning WWF's position is the idea that green capitalism is the only realistic and pragmatic response to ecological crisis. However, WWF's framing glosses over the ways in which extractive uses of nature like mining compete with biodiversity conservation goals and other green development, invoking win-win promises familiar from critiques of neoliberal conservation (Büscher 2013).

From 2015, conservation financing from the extractives sector has been handled by the Biofund, a new conservation trust fund set up in 2011 by WWF, the Mozambican government and donors including the German government and World Bank. Conservation trust funds are public-private partnerships that hold donations from supporters (including from states, donors and the private sector), and provide funding to the conservation sector in the form of grants to NGOs, civil society organisations and state agencies like national parks authorities. While they are predominantly financing agencies, they also provide technical assistance to recipients of funding with the aim of making conservation accountable, transparent and well-governed (Spergel and Taieb 2008). At the launch, it was announced that a central goal of the Biofund is to reconcile the increasing focus on extractives with the idea that development can be sustainable, thus putting WWF's ideas into practice by providing new ways to raise conservation finance directly from the booming extractives sector. Speaking at the launch event, Stephen Stone, Chief of the United Nations Environment Programme, Economics and Trade Branch encouraged the extractives sector to make direct donations to the Biofund:

[I]t is easily conceivable that in auctioning off access to new natural gas or mineral resources, a small fraction of the royalties - and I am talking about a fraction of a percent - are folded back into the Biofund to ensure that current windfalls are also put to work securing the future sustainability of key ecosystems in the country. (UNEP 2015, no page)

At the same time, the AfDB's green economy strategy and Mozambique's Conservation Act of 2014, itself supported by the World Bank and the Peace Parks Foundation, introduced a policy and legal framework for biodiversity off-setting, in which damage to conservation areas can be offset either financially (by contributing to reserves via the Biofund) or directly (by recreating equivalent habitats elsewhere). These mechanisms allow companies to compensate for environmental damage.

In sum, the green economy is, at least in part, a direct response by a closely connected network of major donors, already committed to global principles of natural capital and market-based conservation, to Mozambique's extractives boom. It compresses the contradictory goals of exploiting extractives while also improving biodiversity conservation. The new policy framework introduced by the Conservation Act and supported by the AfDB, WWF, the Biofund and the IUCN would allow the country to continue its extractivesled national development goals, while also making apparent efforts to address the negative social and ecological consequences. Undoubtedly, this relies on a characteristically neoliberal argument that nature can be 
conceptualized as fungible across time and space, adding weight to readings of green economies as mere tokenistic policy-making which provide ideological cover for "'business as usual' capitalism" (Büscher and Fletcher 2015: 273; Sullivan 2017). The green economy is thus especially appealing as it helps donors and elites deal with several pressing questions of extraction, nature conservation, economic development.

However, while assemblages are contingently held together by political need and agreement, they also contain contradiction and friction. With this in mind, I now discuss contradictory uses of green economy ideas. I return to the proposed Techobanine port to explain how green economy ideas are being used to pursue conservation claims which are at odds with the overall green economy strategy of making extraction and conservation compatible.

\section{The Techobanine port and the PPMR: contesting extractives}

Many in Mozambique's conservation communities view the growing extractive sector as a major challenge. This was evidenced by several conversations that I had at the Conservation Policy Workshop in Maputo in April 2014. These were with conservationists including reserve management from the country's various land and marine parks, researchers from the Universidade Eduardo Mondlane and representatives from small NGOs, alongside international donors with an interest in conservation (particularly the IUCN and USAID). However, there are differences in how these groups have responded. Whereas large donors such as WWF, USAID and the IUCN are developing policies around green neoliberalism and biodiversity offsetting as discussed above, other conservationists take a more directly oppositional stance to the green economy even as they share a broader positional space with these donors. Actors engaged in the day-to-day business of conservation as reserve managers, researchers, and in smaller NGO or civil society organizations actors are skeptical of the Mozambican government's commitment to conservation, and feel their interests, which focus on habitat protection and monitoring, species-specific protection and monitoring, poaching and security, and climate change are not taken seriously by the Frelimo government. Where their views diverge is that they feel more free to take a directly oppositional stance to the extractives sector. One activist with a civil society organization suggested that officials do not see a direct benefit from making laws to protect marine environments, but are prepared to make life very easy for extractive companies (interview with Mozambican conservation activist 2, 30 April 2014, Inhambane). An interaction at the Conservation Policy workshop between a senior Frelimo official and attendees illustrates the divergent priorities between this group and some actors in the government. A government official gave a keynote speech on behalf of ANAC which was intended to address the conference's broader interest of conservation policy. However, the speech focused on the need to boost the number and wages of park rangers and to increase the number of tourist beds to increase economic growth. This was considered by almost the entire audience to be completely out-of-step with their concerns about habitat destruction, and his speech was roundly condemned. ${ }^{3}$ Privately, several informants revealed their opinion that this person, despite holding a senior role in conservation did not care about biodiversity and was ignorant of the threats it faced, caring only about business concerns. My subsequent fieldwork reinforced that these views are shared by conservationists engaged in the day-to-day business of conservation as reserve managers, researchers, and in smaller NGO or civil society organizations. They do not trust the Frelimo government and feel it generally does not take their concerns seriously, they believe the government is primarily interested in extraction and industrial growth, and they are concerned that these activities directly threaten their work.

The case of Techobanine port that I introduced in section 2 illustrates the ambiguous position of green economy ideas among Mozambique's conservation community. The PPMR's reserve management in particular believe that the vision that the port represents is at total odds with any sort of ecologically positive future for the reserve, and they are supported in this by the Peace Parks Foundation. The port has been the subject of onand-off rumors since 2010 with various announcements from the government and industry, though few formal

\footnotetext{
${ }^{3}$ The same official highlighted the privileged, Western and white characteristics of many conservation researchers, and claimed conservationists are preoccupied with trivial issues and rare creatures which are of little practical developmental benefit (interview with Frelimo minister, Maputo, 15 May 2014; observations at Conservation Science in Mozambique workshop, April 22-24 2014, Maputo).
} 
plans or processes exist despite a recent round of media announcements in April 2018 (the port has not had a formal Environmental Impact Assessment, for example). One iteration of the proposals is shown in Figure 2, which positions the port complex (thought to also include luxury sports, retail and housing) in the center of the sanctuary part of the reserve, in what one conservationist called "the biggest and the most important coral reef in southern Mozambique" (interview with PPMR official, 9 October 2013).

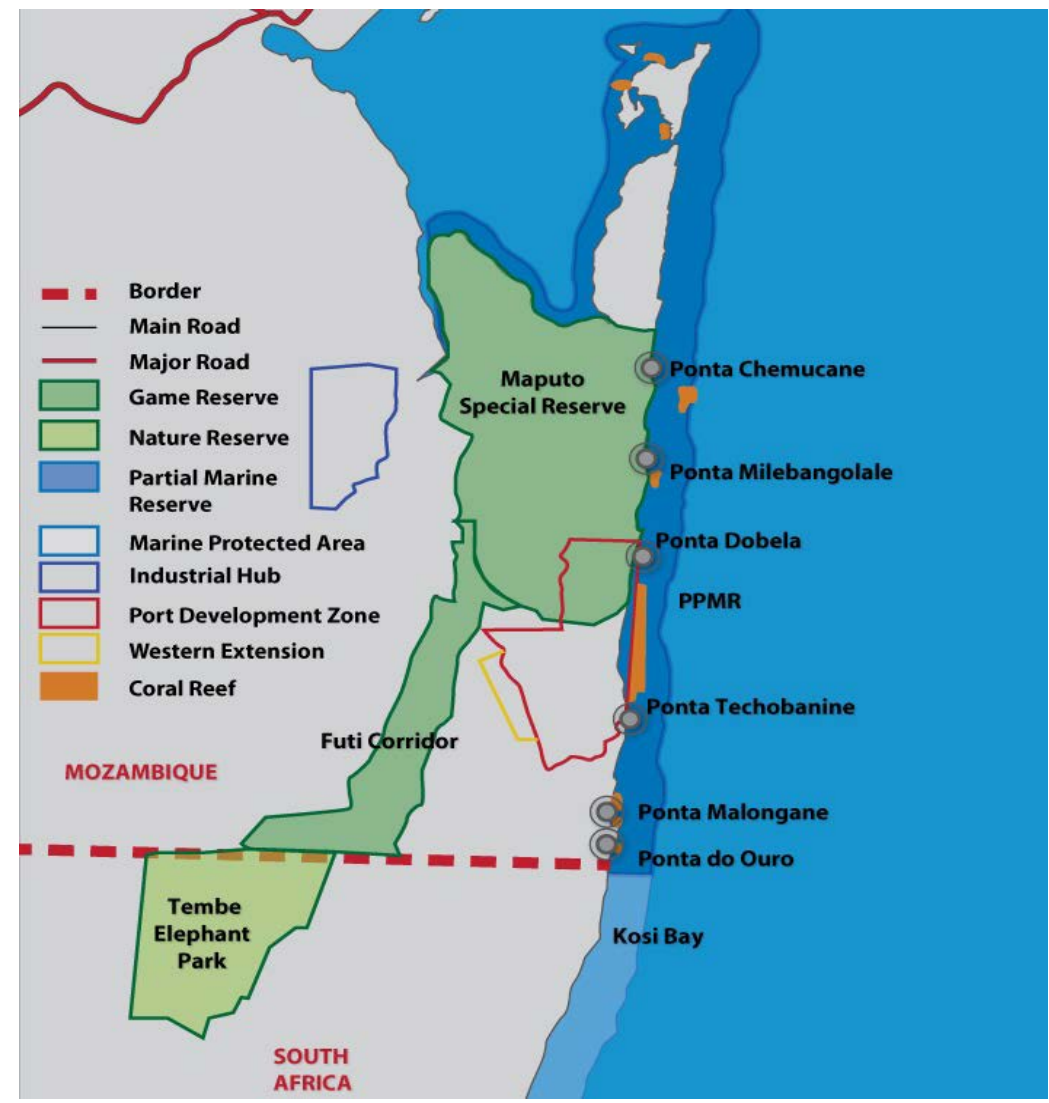

Figure 2: Map of PPMR showing possible location of Techobanine Port Complex. Map designed by Brian Mather.

On paper, the development of a port complex conflicts with the current TFCA land designation as well as with the broader sustainable development goals of the reserve. However, the legal framework protecting the PPMR contains a potential conflict between the proposed port and the TFCA designation, and Mozambique's current land disputes are instructive for understanding how this conflict might play out in the PPMR. All land in Mozambique is owned by the state, and land rights are granted to companies, collectives, organizations or individuals under a DUAT (Direito de Uso e Aproveitamento da Terra, right to use and benefit from the land) (Article 10, Mozambique Land Law, No. 19/97). Article 7 of the Land Law considers conservation areas "total protection zones", the highest level of protection. Moreover, TFCA designations in Mozambique are agreed by the Council of Ministers, again a level of political decision-making which ensures the designations supersede any prior land claims in the area (PPMR 2009: 3). However, in 2014, the Mining Law was revised to establish that economic activities, especially gas and mining, take priority over other land uses where there is economic benefit to the nation (Article 12 and Article 2, Law No. 20/2003, Decree June 2014). While the potential conflict between these articles have not been tested, it is notable that extractive activities have started to take priority over other rights which are also supposed to be highly protected in Mozambique's Land Law, notably 
community land DUATs (Symons 2016). Several informants suggested that Frelimo's focus on extraction at all costs, evidenced in many areas throughout Mozambique, might start to impact conservation protection. It seems likely that if valuable resources were discovered in a conservation area the government may seek to change the designation to enable exploitation. In this vein, it is certainly a possibility that the designation of the existing TFCA could be compromised to accommodate a coal port.

Crucially, it is within this context, defined by uncertainty, lack of trust in Government decision-making and evidence of the pursuit of extraction regardless of environmental costs that supporters of reserves like the PPMR have been negotiating and operating. Consequently, they have themselves engaged in lobbying and political maneuvering to achieve their goals. The idea of a development vision which protects nature through conservation-led tourism is powerful currency in some Frelimo circles, particularly the Ministry for Tourism, providing useful tools that can be used to achieve political goals (interview with former Frelimo minister, April 2014). This new political currency was seized upon by supporters of the PPMR, who lobbied members of the Mozambican Council of Ministers (some of whom are well-known supporters of conservation-led tourism, evidenced by their approval of Peace Parks and reserves throughout the country) to approve the reserve as a UNESCO World Heritage site. This lobbying was conducted throughout 2012 and 2013, and was conducted by reserve officials and the Peace Parks Foundation. The lobbying employed three related tactics which were described to me by a PPF consultant. First, the PPF sought out supportive elements in government (in this case, the Ministry of Tourism) and assisted them with preparing formal opposition to the port. The consultant described how he:

[Asked] the government whether we can support them with independent studies to determine the ecological impact..... partnering with the government on certain studies on the technical side of this. So we are working with government to give them independent, peer -reviewed studies [to counter those undertaken by the port]..... We can work on the nomination, we can work on the current protection, in the presence of a threat, and we address the threat in the context of that. And also working in the trans frontier context of there's a world heritage site on the south African side linking in, and they are being looked at and addressed collectively. So that is our official position. (Interview with PPF consultant, October 2013)

The strategy for formal opposition was to push along a World Heritage designation to link the PPRM with iSimangaliso marine reserve in South Africa which (theoretically, at least) prevents the port, since UNESCO sites must be kept free of extractive uses.

The second line was to demonstrate to government the economic and social value of TFCA programmes in Mozambique. The same informant stated that he communicated to members of MITUR the positive impacts of the PPMR, and the wider investment that the PPF had made in the Lubombo TFCA, suggesting this constituted a long-term alternative to the short-term goals of the port. The numbers that this informant communicated were very large; he suggested to government that the PPF's overall planned investment in Mozambique was US $\$ 870 \mathrm{~m}$, compared to US $\$ 600 \mathrm{~m}$ for the Techobanine project across three countries.

The third message was to frame TFCAs as a sustainable and long-term form of regional economic cooperation through tourism, which would eventually outstrip industrial growth as well as offering more smallscale and equitable economic benefits:

South Africa had very much the same problem with St Lucia coastal mining, and ....... the threat under Richers Bay Minerals. Coastal mining was a massive threat, and [promised] wonderful economics, but government took a decision and decided no, we'll go with the long term approach...... and in the long term it will be more beneficial through small employment, ....... so having this positive growth of tourism across a wide region actually generates more than one big visible impact. So governments, yes, are tempted to look at it [mining], but often by giving them alternatives and information you can actually take decisions in the right direction. (Interview with PPF consultant, October 2013) 
Clearly, the Peace Parks Foundation and the reserve management of the PPMR in Mozambique used their own interpretation of green development reject extractives-led development and protect their vision of the PPMR's future. Indeed, they remain of the opinion that securing the future of the reserve depends on being able to demonstrate to Mozambique's government that the PPMR, and conservation in general, represents an economic gain for the country (telephone call with reserve management, January 2016).

So what to make of conservationist's pragmatic use of green development claims to successfully contest extractives-led industrial redevelopment in this case? Adams (2017) argues that one of the main purposes of green economy discourse is to provide conservation with political influence, in return for acquiescence to neoliberal principles of offsetting and accepting private sector financing. Isn't this precisely what was happening in this case? Undoubtedly, the PPMR's and the PPF's ability to link conservation with economic gains, which made conservation visible to the Frelimo government, are themselves underpinned by strategies which commodify nature. The PPF was able to draw on claims that its Peace Parks can provide regional development, and as such, represents a more 'sustainable' economic future than the short-term benefits of exporting coal. ${ }^{4}$ However, many of the same individuals were critical of the wider green economy agenda of mitigating extraction, and were pessimistic about whether damage to conservation areas could ever be offset, pointing to the uniqueness of Mozambique's conservation areas; and the risks inherent in giving extractives companies an almost free hand in where they operate. Their responses, which noted the unique and irreplaceable aspects of the PPMR, resonated with many of the same criticisms of nature financialization advanced by political ecologists. This is very far from the endorsement of the green economy by these conservation actors.

In sum, the green economy provided reserve management the means to contest extractives-led growth, even as they reworked those narratives through the promise of growth linked to tourism. This case shows that there are strategic political opportunities afforded by the emergence of a neoliberal development narrative which can be seized in ways which alter the original purpose of the discourse. The green economy is shaped by the specific material politics of Mozambique's resource frontiers, and is transformed from a global ecological modernization discourse to something more local.

\section{Conclusions: the tangled politics of extraction and conservation}

This article has discussed the political processes which are shaping Mozambique's green economy. At an ideological and policy level, the green economy has been produced by a combination of factors: as a response to the growing resources boom, through wider shifts in regional economic co-operation, and through international ideas about neoliberal environmental governance. The introduction of the Biofund and the accompanying conservation offsetting regulation provide a way for extractives companies to offset their activities, and to enhance their reputation through funding conservation projects. This has offered a narrative through which conservation actors such as WWF Mozambique can gain political influence, while simultaneously entangling other conservation actors such as reserve managers in the greenwashing of extractive capitalism when this position is far from their personal view on how conservation should proceed. Mozambique's green economy is thus intimately related to its extractives boom, serving as an attempted way to disguise the fundamental tension between Frelimo and private sector elites' ambitions to further exploit nature, and the need to preserve the natural world as a means to support societal and environmental wellbeing (often pressured by donors). Green economy ideas around conservation financing in particular have been extensively promoted through major NGO and international development institutions, particularly WWF Mozambique, the World Bank, the IUCN and the AfDB. Through this process, Mozambique's green economy aims to directly address the contradictions of the extractives sector, and has consequently been welcomed by elites in particular government departments whose agendas are broadly in line with those of major donors (especially the Ministry for Tourism). This case adds to scholarship that views the green economy as an effort to disguise and offset the

\footnotetext{
${ }^{4}$ I acknowledge here that the PPF's activities in southern Africa have been extensively critiqued, and I certainly do not wish to downplay the extent to which the PPF entrenches further nature commodification and has been linked to local dispossessions (Büscher 2013; Symons 2017). Indeed, the neoliberalisation of conservation through the PPF formed a significant aspect of my own research in the region. However, in this article I am concerned with the complex and sometimes ambiguous ways in which green economy discourses are mobilized.
} 
increasing crisis-ridden modes of capitalist production; "a 'pre-emptive strike' precluding any possible chance for the development of sane, animated nature-society engagements" (Büscher and Fletcher 2015: 293).

However, I have also demonstrated that it is important to add nuance to this conclusion. I have shown that Mozambique's green economy aims to substantively reshape current development ideas by suggesting stateled investment in projects and pubic infrastructure, along with fiscal measures to encourage 'green' investment. It is consequently mobilized to provide a vision of a 'new' Mozambique which is explicitly contrasted against 'old' practices of corrupt dealings, private gain, and extraction at all costs (such as those identified with the port). In these aspects, Mozambique's green economy can also be read as a kind of green new deal or 'fourth way neoliberalism' which acknowledges that unfettered markets cause social and ecological problems, and that seeks to redress concern in Mozambique over uneven development though providing major public spending projects. As such, ideological and political debates about the changing role of the state, and about the course that development should take in Mozambique are played out through debates over the green economy. The green economy revives post-independence visions of the state-driven transformation of Mozambique through largescale projects, and, opportunistically, sees the extractives boom as a way of financing such investment, justified under a green development banner. This is, I have suggested, a departure from the neoliberal orthodoxy associated with the green economy, and advocates a change in economic doctrine to emphasize fiscal policy to control ecologically harmful industries, along with large-scale government and private investment into projects and infrastructure.

Through following the debate around Techobanine Port, I have also explored how those who oppose greater degradation through extractive-based exploitation find it beneficial to adopt green capitalist ideas in order to participate in negotiations with the state. Specifically, this strategy has been used by the PPMR reserve management. Situating the PPMR within their own interpretation of green growth, and seeking powerful allies such as the Peace Parks Foundation has enabled them to possibly secure the reserve's future against what the management characterizes as an existential threat driven by a combination of a focus on extraction at all costs, and a mode of political conduct characterized by private gain and elitist development. In this specific scenario, green development ideas may provide an important pragmatic option to oppose extraction and a means to pursue alternative visions of modernity than those of Frelimo's extractives-led development (though at the time of writing it is not clear which vision, the port or the marine reserve, will win out). The green economy thereby poses both threat and opportunity to those in Mozambique who take a stance against extractives-led development: a vision of conservation-led development may prove more appealing to the Frelimo government than a coal port, while at the same time, new legislation couched in green neoliberal terms may also provide for the construction of a port through offsetting. As a member of the reserve management team explained to me in a telephone call in January 2016, that both visions could eventually be described as 'green.'

Wholescale revisions of neoliberal policies and discourses of nature are not necessarily open to actors engaged in development and conservation on the ground. Instead, such actors seek to engage certain aspects of green development to achieve particular goals as afforded by the specific political-economic context. Their strategies may be out of step with political ecologists who advocate an oppositional stance towards neoliberal processes as the only means effective of contestation. The example of the Techobanine port thus foregrounds questions which are often sidelined in political ecology debate, but which appeared as a central concern for many of the people I met in Mozambique:

- How should conservationists navigate a political economy which increasingly accepts the premise of green capitalism?

- Should they resist any attempt to draw nature into the market, or should they strategically engage with such discourses to get what they want?

These questions are currently outside the considerations of political ecology scholarship, which focusses on critiquing nature commodification, but often sidesteps the complex dilemmas which arise between uses and effects of different, yet related commodification strategies. 
In this account I have shown how the green economy appears in Mozambican political life at a time of contestation between opposing agendas of biodiversity conservation and ramped-up extractivism, and how it is mobilized to serve multiple agendas. I have foregrounded how the green economy is linked with Mozambique's post-independence political economy and different visions for national development, and explored how green economy ideas are mobilized to meet particular goals that are shaped by specific political dilemmas. This account of Mozambique's green economy thus attempts to complicate the normative certainties of the neoliberal nature critique of green economies. Rich, context-specific political ecologies are vital to move beyond analyses which draw conclusions based on the production of green economy discourse at a discursive level, and that move towards nuanced accounts of the positionality and role of different actors in relation to 'the' green economy.

\section{References}

Abrahamsson, H. and Nilsson, A. 1995. Mozambique, the troubled transition: from socialist construction to free market capitalism. London: Zed Books.

Adams, W.M. 2017. Sleeping with the enemy? Biodiversity conservation, corporations and the green economy. Journal of Political Ecology 24: 244-257.

AfDB. 2015. Transition towards green growth in Mozambique: policy review and recommendations for action. Cote D'Ivoire: African Development Bank.

AfDB and WWF. 2011. Partnering to promote Green Economy and sustainable development in Africa. Press statement 13/07/2011

Bakker, K. 2009. Neoliberal nature, ecological fixes, and the pitfalls of comparative research. Environment and Planning A 41(8): 1781-1787.

Bakker, K. 2010. The limits of 'neoliberal natures': debating green neoliberalism. Progress in Human Geography 34(6) 715-735.

Bina, O. 2013. The green economy and sustainable development: an uneasy balance? Environment and Planning C: Government and Policy 31(6): 1023-1047.

Blanco Armas, E., E. Gratcheva, D. Pevzner and N. Sharma. 2014. Generating sustainable wealth from Mozambique's natural resource boom. Washington, DC: World Bank Group.

Brand, U. 2009. Environmental crises and the ambiguous postneoliberalising of nature. Development Dialogue 51: 103-118.

Brenner, N., J. Peck and N. Theodore. 2010. Variegated neoliberalization: geographies, modalities, pathways. Global Networks 10(2): 182-222.

Brundtland, G. et. al. 1987. Our common future. Geneva: World Commission on Environment and Development. (the 'Brundtland report')

Büscher, B. 2013. Transforming the frontier: peace parks and the politics of neoliberal conservation in southern Africa. Durham: Duke University Press.

Büscher, B. and V. Davidov. (eds.). 2013. The ecotourism-extraction nexus: political economies and rural realities of (un)comfortable bedfellows. London: Routledge.

Büscher, B., S. Sullivan, K. Neves, J. Igoe and D. Brockington. 2012. Towards a synthesized critique of neoliberal biodiversity conservation. Capitalism Nature Socialism 23(2): 4-30.

Büscher, B. and R. Fletcher. 2015. Accumulation by conservation. New Political Economy 20: 273-298.

Buseth, J.T. 2017. The green economy in Tanzania: from global discourses to institutionalization. Geoforum 86: 42-52.

Castel-Branco, C.N. 2014. Growth, capital accumulation and economic porosity in Mozambique: social losses, private gains. Review of African Political Economy 41(sup1): 26-48.

Castree, N. 2008. Neoliberalising nature: the logics of deregulation and reregulation. Environment and Planning A 40(1): 131-152. 
Cavanagh, C.J. and T.A. Benjaminsen. 2017. Political ecology, variegated green economies, and the foreclosure of alternative sustainabilities. Journal of Political Ecology 24: 200-341.

Club of Mozambique. 20 April 2013. Concession awarded for construction of Techobanine port. Available at: http://www.clubofmozambique.com/solutions1/sectionnews.php?secao=business\&id=28370\&tipo=on

e (accessed 19 September 2017.

Club of Mozambique. 25 May 2016. Botswana plans to share construction costs of Techobanine port in Mozambique. Available at: http://clubofmozambique.com/news/botswana-plans-to-share-constructioncosts-of-techobanine-port-in-mozambique/ (accessed 19 September 2017).

Club of Mozambique, 16 April 2018. Botswana, Zimbabwe forge ahead with US\$600m rail project to Mozambique's Techobanine port. Available at: http://clubofmozambique.com/news/botswanazimbabwe-forge-ahead-with-us600m-rail-project-to-mozambiques-techobanine-port/ (accessed 13 September 2018).

Corson, C., K.I. MacDonald and B. Neimark. 2013. Grabbing "green": markets, environmental governance and the materialization of natural capital. Human Geography 6(1): 1-15.

Davidson, S. 2012. The insuperable imperative: a critique of the ecologically modernizing state. Capitalism Nature Socialism 23(2): 31-50.

Death, C. 2014. The green economy in South Africa: global discourses and local politics. Politikon 41(1): 122.

Fairhead, J., M. Leach and I. Scoones. 2012. Green grabbing: a new appropriation of nature? Journal of Peasant Studies 39(2): 237-261.

Ferguson, J. 2010. The uses of neoliberalism. Antipode 41(s1): 166-184.

Ferguson, J. 2015. Give a man a fish: reflections on the new politics of distribution. Durham: Duke University Press.

Ferguson, P. 2015. The green economy agenda: business as usual or transformational discourse? Environmental Politics 24(1): 17-37.

Government of Mozambique, Land Law 1997 Law no. 19/97 of 1 October

Government of Mozambique, Mining Law 2003, Decree 28/2003 of June 17, 2014.

Government of Mozambique 2012a. Towards a Green Economy: Roadmap for a Green Economy in Mozambique. Accelerating sustainable economic, social, and environmental development, June 7, 2012. Maputo.

Government of Mozambique 2012b. Mozambique emerges as a Green Economy at Rio+20. Press statement available

at: http://static1.1.sqspcdn.com/static/f/1058662/19736235/1344262747443/rio20_mozambiquegreenecon omy.pdf?token=2cAjRQR\%2BNiCGdKBkKQuVc7BczRA\%3D (accessed 10 August 2016).

Government of Mozambique, Conservation Areas Law. 16/2014 of the 20th of June.

Hanlon, J. and T. Smart. 2008. Do bicycles equal development in Mozambique? Oxford: James Currey.

Hanlon, J. 2016. 9 June 2016. Mozambique: hoping 'something will turn up'. AllAfrica.com. Available at http://allafrica.com/stories/201606131636.html (accessed 17 June 2016).

Harvey, D. 2005. A brief history of neoliberalism. Oxford: Oxford University Press.

Huberman, D. 2010. A guidebook for IUCN's thematic programme area on greening the world economy (TPA5). Gland: IUCN.

Kirshner, J. and M. Power. 2015. Mining and extractive urbanism: postdevelopment in a Mozambican boomtown. Geoforum 61: 67-78.

Li, T.M. 2007. Practices of assemblage and community forest management. Economy and Society 36(2): 263293.

Li, T.M. 2014. What is land? Assembling a resource for global investment. Transactions of the Institute of British Geographers 39(4): 589-602. 
MacauHub.com. 2016. Botswana, Mozambique and Zimbabwe plan to build railway. Available at: http://www.macauhub.com.mo/en/2016/09/05/botswana-mozambique-and-zimbabwe-plan-to-buildrailway/ (accessed 12 October 2016).

Mondlane, E. 1969. The struggle for Mozambique. Baltimore: Penguin Books.

Moore, J.W. 2015. Capitalism in the web of life. London: Verso Books.

Nhamo, G. 2013. Green economy readiness in South Africa: a focus on the national sphere of government. International Journal of African Renaissance Studies 8(1): 115-142.

OECD. 2011. Towards Green Growth. Paris: OECD Publishing.

Peck, J. 2010. Constructions of neoliberal reason. Oxford: Oxford University Press.

Ramesh, M. and N.D. Rai. 2017. Trading on conservation: a marine protected area as an ecological fix. Marine Policy 82: 25-31.

Resnick, D., F. Tarp and J. Thurlow. 2012. The political economy of green growth: cases from Southern Africa. Public Administration and Development 32(3): 215-228.

Siamanta, Z.C. 2017. Building a green economy of low carbon: the Greek post-crisis experience of photovoltaics and financial' green grabbing'. Journal of Political Ecology 24: 258-276.

Sidaway, J.D. and M. Power. 1995. Socio-spatial transformations in the 'post-socialist' periphery: the case of Maputo, Mozambique. Environment and Planning A 27(9): 1463-1491.

Southern Times. 2018. Bots, Zim forge ahead with US\$600m rail project. 13 April 2018. Available at: https://southerntimesafrica.com/site/news/bots-zim-forge-ahead-with-us600m-rail-project (accessed 22 September 2018)

Spergel, B. and P. Taieb. (eds.). 2008. Rapid review of conservation trust funds. Available at http://imap.cciforum.org/pdfs/Rapid\%20Review\%20CTFs\%20May\%2008\%20Final.pdf (accessed 22 September 2017)

Sullivan, S. 2017. What's ontology got to do with it? On nature and knowledge in a political ecology of the 'green economy'. Journal of Political Ecology 24: 217-242.

Symons, K. 2016. Transnational spaces, hybrid governance and civil society contestation in Mozambique's gas boom. The Extractive Industries and Society 3(1): 149-159.

Symons, K. 2017. Trans-frontier conservation and the neoliberalisation of nature: the case of the Ponta do Ouro Partial Marine Reserve, Mozambique. PhD dissertation. University of Edinburgh.

The Telegraph (November 2014). The Minister, the Mine and the £1,300-an-hour Payday. (14 November 2014). Available at:

http://www.telegraph.co.uk/news/worldnews/africaandindianocean/mozambique/11233343/Theminister-the-mine-and-the-1300-an-hour-payday.html (accessed 12 August 2016).

Tsing, A. 2005. Friction: an ethnography of global connection. Princeton: Princeton University Press.

UNEP. 2011. Towards a green economy: pathways to sustainable development and poverty eradication. Available at: http://web.unep.org/greeneconomy/resources/green-economy-report (accessed 22 September 2017).

UNEP. 2015. Mozambique, the Biofund, and moving towards post-extractive economies: reflections on the nature of wealth - and the wealth of natures. A speech by Dr. Steven Stone, Chief of the United Nations Environment Programme, Economics and Trade Branch. 11 June 2015, Maputo. Available at: https://www.unenvironment.org/news-and-stories/news/mozambique-biofund-and-moving-towardspost-extractive-economies-reflections-0 (accessed 28 September 2018).

Vines, A. 2013. Mozambique's 20 years of peace at risk? London: Chatham House.

Vladimirova, V. 2017. Politics of the green economy in Russia's European North. Journal of Political Ecology 24: 200-341.

Walker, M.M. 2015. Producing Gorongosa: space and the environmental politics of degradation in Mozambique. Conservation and Society 13(2): 129. 
Wanner, T. 2015. The new 'passive revolution' of the green economy and growth discourse: maintaining the 'sustainable development' of neoliberal capitalism. New Political Economy 20(1): 21-41.

WWF. 2012a. Press release: green economy to help make poverty history in Mozambique. Available at: http://wwf.panda.org/wwf_news/?205451/Green-Economy-To-Help-Make-Poverty-History-inMozambique (accessed 12 October 2016).

WWF. 2012b. Towards a green economy in coastal East Africa. Briefing paper. Available at http://d2ouvy59p0dg6k.cloudfront.net/downloads/coastal_east_africa_green_economy.pdf (accessed 10 August 2012). 